\title{
Community As Brand: An Exploratory Investigation
}

\author{
Christine Wright-Isak, Florida Gulf Coast University, USA
}

\begin{abstract}
This research investigates how community affects consumer marketing and brand equity management. Community is a ubiquitous concept with many definitions in social sciences, ranging from urban neighborhoods and small towns to brand communities. Firms utilize the power of brands to support premium prices, sustain product value in difficult circumstances, and persuade consumers to purchase a brand repeatedly and loyally. Brand scholarship has also ranged widely, from tangible product or service characteristics to the intangible influence of its symbols and meanings on consumers. This study describes how the complicated sets of meanings embedded in the terms community and brand lead to a phenomenon called naturally occurring brands (NOBs). The paper combines the anthropology, sociology and marketing perspectives to describe the NOB phenomenon and explores its validity using survey research.
\end{abstract}

Keywords: Branding; Community Brands; Brand Equity; Small Town; Suburbia; Cultural Icons

\section{INTRODUCTION}

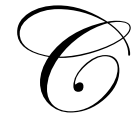

ommunity has many definitions in the social science fields. Research has ranged from urban neighborhoods (Suttles, 1968), and small towns (Vidich \& Bensman, 1968) to brand communities (Muniz \& O'Guinn, 2001). Branding as a strategic business activity is widespread in business scholarship and practice today (Aaker, 1996; Fournier, 1998). Firms recognize the power of brands to support premium prices, sustain product value in difficult circumstances, and generally persuade consumers to purchase a given brand loyally and repeatedly (Aaker \& Biel, 1993; Tybout and Sternthal, 2005). Brand scholarship has also ranged widely, from tangible product or service attribute considerations to the intangible influence of symbols and meanings on consumer perceptions. Some scholars have combined the two ideas to explain consumer behavior (Kotler, Haider, \& Rein, 1996; Muniz \& O'Guinn, 2001).

\section{PURPOSE}

This study synthesizes anthropology, sociology and marketing perspectives to describe how complicated sets of meanings embedded in the terms community and brand lead to discovery of a phenomenon called naturally occurring brands (NOBs). Next, the NOB phenomenon is defined and its validity is explored using survey research.

\section{COMMUNITY AND BRANDING THEORY AND RESEARCH}

\section{Social Theory Antecedents: Community}

Definitions of community across social science fields range from the tangible to the intangible. At the most literal or tangible end of a conceptual spectrum, community refers to places as items to be marketed in order to enhance their value, with place names acting as brands (Kotler, Haider, \& Rein, 1996). At the symbolic or intangible end lies the symbolic construction of communities (Cohen, 1985). In-between are communities that combine actual place and social order with symbolic dimensions in one entity (Suttles, 1968; Gans, 1967; Kornblum, 1974) intermittent or episodic communities (Belk, Sherry, \& Wallendorf, 1988), and intentional communities created by purposive collective behavior efforts to live within alternative belief systems (Zablocki, 1979; Zablocki, 1981). At its heart, any community addresses the human desire for belonging. The typological 
spectrum proposed in this study construes the nature of belonging, the bond between person and community, as central to each definition. These experiences of affiliation with various forms of community range from the utilitarian to the emotional.

Kotler, Haider, \& Rein (1996) focus on the tangible or utilitarian definitions of community as place. Place marketing is the most literal definition of community where the value of a geographic space occupied by residents, businesses and/or visitors, varies partly in response to deliberate efforts to create a desire for it. They focus on the marketing objectives for particular places (mostly cities) of attracting tourists, industry or workers on the basis of functional attributes like tropical climate, low taxes and good schools. Theirs is an economic growth model in which features of a place are used to position and promote it. Their emphasis is on product attributes rather than its cultural meaning or significance. They expect an implicitly utilitarian consumer calculus of place advantages in exchange for the resources like tax revenues, tourist dollars, and development momentum. In this approach brands are little more than labels for clusters of features. Consumer motivation to belong to a community is not part of their framework.

Sociologists add social meaning to place-defined communities. They focus on human interactions, the norms of how people behave and the perceptions they do or do not share about how groups in the boundaried territory of a community think and act within a boundaried space (Anderson, 1978; Kornblum, 1974; Suttles, 1968; Zablocki, 1979). Community in this body of scholarship describes a category of human belonging more encompassing than family or tribe, but smaller in classifying scope than city. Individuals' motivations toward the choice of one or another specific place include the anticipated satisfaction of a certain kind of belonging (WrightIsak, 1985).

Among the most sociologically detailed and socially intimate community studies we find ethnographies of American urban places described by Suttles (1968) in which neighborhood dwellers within the city of Chicago maintain their own boundaried enclave of familiars or by Vidich \& Bensman (1968) which describes the attitudes and behaviors of small town residents in contrast to city dwellers. In response to the post World War II housing boom, Gans (1967) studied the newly forming suburban enclaves as a third type that emerged along with television and the nuclear family. In these sociological studies the repeated interactions of neighbors and the social norms and shared values characteristic of the community are the focus of inquiry and analysis.

Constance Perin (1977) investigates how neighbors in American communities enact land use contracts as a key mechanism of how neighbors think, feel, and act toward one another. Perin studied many communities in the United States in the 1960's by examining the specific intersection of macro-level geographic community and microlevel neighborly behaviors in suburbs. She describes how zoning regulations guide dispute resolutions and neighborly cooperation, affecting property values as well as community residential satisfaction. Her work enables us to generalize about how geographic place and social bonds of community actually intersect.

In the area of intentional communities, the examination of communitarian efforts in America by several scholars in the 1970's range from early American Utopian efforts of the $19^{\text {th }}$ century (Hayden, 1976) to participant observations of intentional communities in development in the 1960's (Zablocki, 1979).In addition to the unique aspects of norm and belief, these studies examine the nature of social structures and processes such efforts have in common with other forms of community. Zablocki (1981) studied 120 communitarian attempts in the U.S. aiming to uncover which of these factors lead to the organizational success or failure during intentional efforts to build and manage actual communities.

The relevance of communitarian studies for marketers is in the lessons their findings offer to those attempting to segment consumer subcultures. Their descriptions demonstrate the complexity of human efforts to transform intentions into common understanding of values. They display the even greater difficulty humans have in agreeing on common actions to fulfill the values they do agree on.

Thus, sociologists view community as a complex of patterned social interactions among individuals that give rise to consistent sets of expectations about how daily life will occur. Further, they understand that places are transformed into communities through the social bonds that unite individuals within it. For them the name of the place may have several kinds of political, socio-cultural and economic significance, but they do not construe it as a brand. 
Finally, some communities are episodic social places and cultural signals. Scholars have expanded the definition of community to include community formation and re-creation, with social bonding taking place via recurring rituals of consumption. These are the ethnographies of consumers as they meet regularly in local restaurants (Duneir, 1969), at swap meets (Belk, Sherry \& Wallendorf, 1988), or in flea markets (Sherry 1990). These consumers are intermittently drawn to enacting social bonds of community at pre-set times and places. In these periodic but temporary communal settings they participate in behaviors guided by social norms emerging over time among regular attendees. Moreover, these norms of behavior shape individuals' perceptions and choices while they are participating in consumption. In occasion-based communities the locations of any particular one can change (Belk, Sherry \& Wallendorf, 1988) but their customs and norms are consistent from one place and one occasion to another (Sherry, 1990).

\section{Social Theory Antecedents: Brands and Branding}

Americans use brands to identify alternatives and make choices. Manufacturers or service providers use them to signal consumers to their particular offerings. In both cases brands are signs that signify sets of features and benefits (Calkins 2005, Tybout \& Sternthal, 2005). In addition, consumers come to associate these symbols with personal experiences in the course of acquiring and using a particular brand. These personal impressions accumulate and add to a brand's perceptual equity. As perceptions are shared among the consumer's family, friends and acquaintances, the brand becomes a collective source of cultural transmission of meanings beyond the individual's set of understandings (Thomson, MacInnis, \& Park, 2005).

Like community, the concept of brand has evolved from utilitarian or tangible definitions (Kotler, Haider, \& Rein, 1996; Tybout \& Sternthal, 2005) to brand value based on experiences, services or conferred status (Rust, Zeithaml, \& Lemon, 2004). At the emotional end of the spectrum the two concepts have been combined based on affiliation of groups of consumers around a given brand and what it signifies to them (Muniz \& O'Guinn, 2001; Sherry, 2005).

Applying community research to brand communities, Muniz and O'Guinn (2001) borrowed from sociology to unpack the underlying symbolic phenomena that affect consumer loyalty to brands. They explicitly highlight the relevance of the brand/community intersection, observing how consumers who are likely to bond on the basis of shared beliefs and values identify each other by their common affinity for a particular brand. The brand symbol comes to signify a communal set of beliefs and values shared by its consumers.

Muniz and O'Guinn further assert that a brand stands for more than a set of attributes and features. It serves as a totem that calls like-minded consumers together, in spirit if not literally. Using the examples of the Jeep and Zima brands, their work demonstrates how a brand may offer belonging as one of its benefits. Consumption of each of these brands expresses commitment to a particular community of people who share some of an individual consumer's own perceptions and desires about how to live.

Brand communities borrow elements of all the previously described conceptualizations of community. The brand itself is the place where community happens. Social structures of meaning and custom emerge among regular consumers of the brand. However, brand communities may not include actual encounters among fellow consumers of the brand. Their autonomous behaviors, organized around the shared meaning of the brand, are similar to the face-to-face actions to form community studied by Hayden (1976), Zablocki (1979) and others. Acts of affiliation with the brand achieved through consuming enable consumers to achieve communion (real or imagined) with others who also consume it.

In these studies the creation and maintenance of the brand's meaning is implicitly the activity of its marketer. Schouten and Alexander (2005) shift focus to consumer constructions of brand meaning. In studying the Harley Davidson brand, they demonstrate how consumers amplify a brand's meaning by bringing their own actions and visual style to the constellation of associations made to the brand. Consumers can autonomously contribute user imagery to the understandings their culture has about the brand, often in ways unimagined or unintended by its marketers. 


\section{Brands as Icons}

Holt (2003) examines the transformation of five commercially marketed brands into cultural icons. His work demonstrates how even commercially created symbols can unite consumers in common understanding of cultural meanings. Holt takes an historical perspective of brands like Apple, Nike and Harley-Davidson, describing each in terms of how it enters a constellation of meanings centered around a core American value. Such themes include individual independence in the face of corporate dominance (Apple's 1984 brand advertisement), or American enterprise and initiative (Nikes "Just Do It" slogan) or the rugged individualism with a uniquely American admiration for the outlaw represented in the Harley-Davidson brand imagery.

In Holt's model, community does not play an explicit role. Consumers share common understanding of a brand's iconic significance independently from one another. Although Holt takes the perspective of the marketer's intentional construction of brand meaning, he does recognize that these brands gain their reputational power by evoking loyalty on the basis of consumers' shared affinities for the brand's deeper cultural meanings.

In contrast to a marketer-down perspective, John Sherry (2005) views branding primarily from the consumer's point of view. Like Schouten and Alexander, he focuses on consumers' autonomous impact on brand meaning. In identifying how brands accumulate multiple meanings, he recognizes that post-modern culture is made up of consumers who actively engage in the search for meaning. In these post-modern quests they rely less on nature and more on images or artifacts created by marketers. Modern humans are homo quaerens, "those who search," and their world is super-mediated by marketers (Sherry, 2005, p. 43). This synthesis of community and brand scholarship is summarized in Table 1 below.

\section{A NEW BRANDING CONCEPT}

The convergence of these varied perspectives on community and brands depends on acknowledging that symbols are phenomena of meaning creation and revision (Sherry 2005). This paper proposes that just as brands may be consciously created, maintained or transformed by commercial interests, some brands may naturally emerge into the culture's symbols and meanings without any intentional promotion. They achieve their symbolic significance as a result of unmanaged social processes and cultural evolution. They comprise a phenomenon that this paper describes as naturally occurring brands.

The widely understood and ubiquitous meanings of both community and brand leads to the conclusion that the commonly identified types of community, city, small town, or suburb, are clear examples of what may be called naturally occurring brands (NOBs). Three criteria define NOBs:

- They are not commercially created and their imagery is not deliberately managed by a corporate actor. No entity owns or has trade-marked, copyrighted, or otherwise exclusively appropriated the terms city, small town or suburbia. Instead their meanings have arisen and persist as a result of consistent patterns of social interactions and shared meanings. Thus, they are naturally occurring labels for acquirable phenomena.

- $\quad$ They are widely recognized to the point of being understood as more than a one-dimensional taxonomy applied to a geographic type of place. As symbols each has visual characteristics and stands for a cluster of specific human norms and enacted values. These sets of meanings characterize the type of place and shape the behavior of the individuals who dwell in or visit them. They draw like-minded residents together in agreement on meaning and they are judged by outsiders on these same meanings. Thus, they are brands.

- $\quad$ They affect consumer choices - of whether or not to live in a given place - depending on whether or not they want a small town, suburban or urban way of life. They operate on consumer judgments just as intentionally created and marketed brands do in affecting consumer preferences and actions. This third characteristic may be the strongest indicator that they are brands.

\section{The Basis of the Research Theory and Measures Advanced in This Paper}

While the above description makes conceptual sense, it is theoretically prudent to investigate the plausibility of the idea in daily social life. The research in this paper explores whether or not consumers understand 
these naturally occurring brands to have the same meanings as those given them by community scholars and earlier research participants. It asks whether or not each of these community brands does hold commonly understood meaning in today's popular culture. Should that be the case, theory about how perceptions of them shape consumer choices can be investigated in future research.

Table 1 - Community and Brand Theory Convergence: From Literal to Symbolic

\begin{tabular}{|c|c|c|c|}
\hline $\begin{array}{c}\text { Authors (listed from } \\
\text { most literal to most } \\
\text { symbolic) } \\
\end{array}$ & Community Types & Brand Concepts & $\begin{array}{c}\text { Authors (listed from } \\
\text { most literal to most } \\
\text { symbolic) } \\
\end{array}$ \\
\hline $\begin{array}{l}\text { Kotler, Heider \& Rein } \\
\text { (1996) }\end{array}$ & $\begin{array}{l}\text { Place (Geographic) } \\
\text { Marketing named Cities and States } \\
\text { (e.g. Boston or Boulder, Colorado); } \\
\text { Low interpersonal communion and } \\
\text { high cost-benefit based } \\
\text { commitment. }\end{array}$ & $\begin{array}{l}\text { Utilitarian Feature-based } \\
\text { Branding } \\
\text { Brand as label for a given } \\
\text { combination of functional } \\
\text { performance features. Usually } \\
\text { refers to products. }\end{array}$ & $\begin{array}{l}\text { Kotler \& Armstrong } \\
(2010) \\
\text { Keller (1998) }\end{array}$ \\
\hline $\begin{array}{l}\text { Gans (1967) } \\
\text { Suttles (1968) } \\
\text { Vidich \& Bensman } \\
\text { (1968) } \\
\text { Duneir (1969) } \\
\text { Anderson (1978) }\end{array}$ & $\begin{array}{l}\text { Community as bounded territory } \\
\text { Place studied for its inextricable } \\
\text { connection to social bonds, norms, } \\
\text { rituals of residents. } \\
\text { Based on economic, social \& } \\
\text { emotional attachment to actual } \\
\text { place \& fellow inhabitants. }\end{array}$ & $\begin{array}{l}\text { End-Benefit based Branding } \\
\text { Brand emphasizes social or } \\
\text { emotional benefits like status, } \\
\text { security or peace of mind. Can } \\
\text { also include brand consumption } \\
\text { as self expression. Products and } \\
\text { services are both included in this } \\
\text { model. }\end{array}$ & $\begin{array}{l}\text { Keller (1998) } \\
\text { Tybout \& Sternthal } \\
(2005) \\
\text { Kotler (2010) } \\
\text { Calkins (2005) }\end{array}$ \\
\hline $\begin{array}{l}\text { Hayden (1976) } \\
\text { Zablocki (1979) }\end{array}$ & $\begin{array}{l}\text { Intentional Community } \\
\text { Communion and commitment based } \\
\text { on expected personal behaviors to } \\
\text { enact shared values and beliefs. }\end{array}$ & $\begin{array}{l}\text { Brand Community } \\
\text { Brand sign helps fellow } \\
\text { consumers of a brand with } \\
\text { similar values gather. }\end{array}$ & $\begin{array}{l}\text { Muniz \& O'Guinn } \\
\text { (2001) }\end{array}$ \\
\hline $\begin{array}{l}\text { Belk, Wallendorf \& } \\
\text { Sherry (1988) } \\
\text { O’Guinn \& Belk (1989) }\end{array}$ & $\begin{array}{l}\text { Episodic Consumption } \\
\text { Community } \\
\text { Norms \& belonging arise in places } \\
\text { regularly set up for trade. }\end{array}$ & $\begin{array}{l}\text { Episodic Brand } \\
\text { Consumers regularly join in } \\
\text { events united by brand. }\end{array}$ & $\begin{array}{l}\text { Schouten \& Alexander } \\
(2005)\end{array}$ \\
\hline Wright-Isak (1985) & $\begin{array}{l}\text { Small Town, Suburbia, City are } \\
\text { labels with distinct, commonly used } \\
\text { meanings. }\end{array}$ & $\begin{array}{l}\text { Brand Tribalism } \\
\text { Imagined belonging among } \\
\text { fellow consumers or admirers of } \\
\text { the brand. }\end{array}$ & $\begin{array}{l}\text { Cova \& Cova (2001) } \\
\text { Veloutsou \& Moutinho } \\
(2009)\end{array}$ \\
\hline Cohen (1985) & $\begin{array}{l}\text { Symbolic Community } \\
\text { Communion of people becomes } \\
\text { community based on shared } \\
\text { perceptions of what it means. }\end{array}$ & $\begin{array}{l}\text { Brand as Icon } \\
\text { Autnonmously understood } \\
\text { symbol associated with a clearly } \\
\text { understood meaning. }\end{array}$ & $\begin{array}{l}\text { Holt (2003) } \\
\text { Sherry (2005) }\end{array}$ \\
\hline Sherry (2005) & $\begin{array}{l}\text { Communion of Meaning } \\
\text { Symbols, brands are commonly } \\
\text { understood signposts of meaning. }\end{array}$ & $\begin{array}{l}\text { Constellations of Cultural } \\
\text { Symbols \& Meanings } \\
\text { Brands meanings result from a } \\
\text { process of social collaboration. }\end{array}$ & Sherry (2005) \\
\hline
\end{tabular}

Wright-Isak (1985) challenged Vidich and Bensman's (1968) predicted demise of American small towns in the face of encroaching urban life and culture. Her multi-method qualitative research found that three types of place labels were offered by consumers as key factors in their choice of where to live: city, suburbia, and small town. They used these terms to characterize their perceived alternatives in buying a home. The study inadvertently revealed the possibility that community is being used by consumers in the same way brands are being used in modern culture, as signposts of relevant meaning that offer clues to post-purchase satisfaction.

Consumers described the three communities using distinct visual imagery, associated with distinct sets of expectations regarding how neighbors would behave toward one another. Actual experience was apparently not how 
they learned the meanings of each type. Many indicated their perceptions arose from portrayals of communities in American literature, cinema, television and music.

\section{METHODOLOGY}

\section{Research Design}

This research investigates whether boomers and millennials today ascribe the same meanings to small town, city, and suburbia as earlier research indicates. If they do, it will indicate that the NOB concept can actually exist in $21^{\text {st }}$ century U.S. culture. Using contemporary data from 50 surveys with both generations, the associations and interpretations respondents make regarding what community means is explored 25 years after the first study.

The sample includes undergraduate students representing the millennial generation and consumers whose dates of birth makes them boomers. The survey questions were developed using the homeowner detailed descriptions from the 1985 study. The current study was fielded in Florida in 2009-10 using both verbal and nonverbal stimuli with 25 millennial consumers and 25 boomers as the pretest for a larger study.

\section{Survey Instrument}

Some questions measure associations of community attributes with the imagery of the three NOBs, small town, suburbia and city. Others inventory possible sources of meaning of the types, namely television shows, and books. The attributes associated with the three types provide the basis for identifying consensus on the meanings of each of these NOBs. The book and TV consumption measures provide some indication of how brand meanings might be transmitted from one generation of consumers to another.

The questionnaire used one black \& white, unlabeled, photograph to portray each of the three types of community. Participants rated each photo on 15 descriptors (attribute statements) using a 5-point Lickert scale of agree completely (5) to disagree completely (1) that the descriptor accurately characterizes the image being rated. Negative and positive descriptors were included for each type. Each of the three community images was rated on all 15 attributes. The sequence of attributes, as well as the page order in which the pictures appeared, were rotated to avoid sequence effects.

The attribute list included five (5) descriptors expected to be associated (agree) with each type of community. Table 2 below displays the measures and the type of community for which each was theoretically expected to score high in agreement that the statement describes the type in the picture. Following the community ratings, participants were asked to label each image by its NOB label, small town, suburb or city.

\section{Theoretical Expectations}

Since successful commercially created and maintained brands have widespread understanding throughout the culture, theory expects to find common understandings of the meanings of these naturally occurring community brands across the generations included in the sample. However, today's youth are often thought to be very different than previous generations (Crampton \& Hodge, 2009; Noble, Haytko, \& Phillips, 2009).

Therefore we expect that millennials, being at least one, and in some instances two, generations away from the respondents in the original study will have different understandings than those of boomers regarding the brand meanings of the three types of community. The boomers in 1985 had described each community in the following manner:

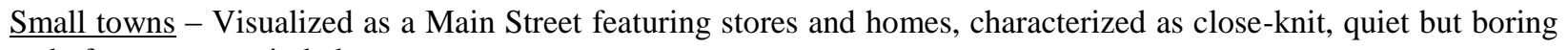
and often narrow minded.

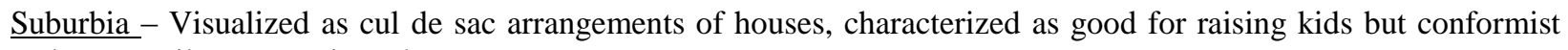
and monetarily status oriented. 
Cities - Visualized as crowded collections of row homes and high rises, characterized as sophisticated and trendy but noisy and often dangerous.

Table 2 displays the full set of measured descriptors, organized to show which type of community is expected to be characterized by each set of five. Because of the small sample and its use as a pre-test for an anticipated larger study, we analyzed the data in qualitative form, comparing average ratings of descriptors and communities but not attempting statistical comparisons.

Table 2 - Theoretical Expectations of Community Perceptions

\begin{tabular}{|l|c|}
\hline \multicolumn{1}{|c|}{ Descriptor } & Community with High Agreement \\
\hline People here tend to hold traditional values & Small Town \\
\hline People here tend to be narrow minded & Small Town \\
\hline Everyone is expected to conform here & Small Town \\
\hline A place where people volunteer to help their neighbors & Small Town \\
\hline Safe and quiet but totally boring & Suburbia \\
\hline This is the place to find soccer moms & Suburbia \\
\hline Like the place where I grew up & Suburbia \\
\hline Your status here is based on how much money you have & Suburbia \\
\hline A place people move to for raising their children & Suburbia \\
\hline Everyone is expected to conform here & City \\
\hline This is where the latest trends are started & City \\
\hline A place to live before I settle down & City \\
\hline Noisy and often dangerous & City \\
\hline A place where I can be free to discover myself & City \\
\hline People here tend to "live and let live" & \\
\hline
\end{tabular}

\section{RESULTS}

First the sample as a whole was examined for correct association of the questionnaire stimulus pictures with the labels of small town, city, and suburb. Ninety-one percent correctly associated all three with their proper label. The nine percent who did not confused the small town picture with suburb. All identified the city image correctly. As it can be seen in Table 3, both generations of today's consumers see the communities generally as the theory predicts. The shadowed boxes highlight the expected five descriptors for each type of community and show them to have highest average ratings.

\section{Comparing Generations' Perceptions}

In Table 4 below, the five characteristics on which each NOB is most highly rated are compared for boomers and millennials. The data indicates that millennials make similar or same associations of descriptors for each community as the boomers do. This suggests that the constellation of meanings for each of the NOBs is understood by millennials and boomers alike.

In order to explain how the observed similarity of community brand perceptions might occur, book readership and TV viewership were also measured. Respondents were provided with two lists of items, one of books read and one of TV shows watched. They checked off each one read or seen. Each book or TV show on the lists was selected for its portrayal of one of the community types as the backdrop for its fictional drama or comedy. Table 5 below shows how many of each generation checked each book read or each TV show seen.

A very high overlap of books read and television shows watched by both generations is observed, a pattern of findings consistent with what the 1985 participants said concerning where they got their ideas regarding each type of community. The contemporary TV Land network in particular has enabled millennials to view the same shows (e.g., Mayberry RFD, Ozzie and Harriet, and Family Ties) as older generations. It may be that many of the books in the list are those assigned in junior or high school curricula for both generations. 
Table 3: Total Sample Ratings by Community Brand

Scale: $1=$ disagree completely to 5=agree completely

\begin{tabular}{|c|c|c|c|}
\hline Descriptor & & $\begin{array}{c}\text { AVG Ratings } \\
(\mathbf{n}=50)\end{array}$ & \\
\hline & Small Town & Suburbia & City \\
\hline People here tend to hold traditional values & 3.97 & 3.56 & 2.61 \\
\hline People here tend to be narrow minded & 3.34 & 3.27 & 2.85 \\
\hline Everyone is expected to conform here & 3.09 & 2.16 & 2.26 \\
\hline A place where people help their neighbors & 3.30 & 3.84 & 2.25 \\
\hline \multirow{2}{*}{ Safe and quiet but totally boring } & 3.64 & 2.84 & 1.69 \\
\hline & AVG 3.48 & AVG $\quad 3.17$ & AVG 2.33 \\
\hline This is the place to find soccer moms & 2.46 & 3.77 & 1.87 \\
\hline Like the place where I grew up & 3.14 & 2.76 & 2.30 \\
\hline Your status is based on the money you have & 2.99 & 3.12 & 1.57 \\
\hline A place people move to for raising their children & 2.56 & 2.91 & 3.53 \\
\hline \multirow[t]{2}{*}{ Everyone is expected to conform here } & 2.91 & 4.02 & 2.11 \\
\hline & AVG $\quad 2.81$ & AVG $\quad 3.32$ & AVG 2.28 \\
\hline This is where the latest trends are started & 1.77 & 2.36 & 3.44 \\
\hline A place to live before I settle down & 2.04 & 2.61 & 3.31 \\
\hline Noisy and often dangerous & 1.45 & 1.86 & 3.61 \\
\hline A place where I can be free to discover myself & 2.32 & 2.82 & 3.44 \\
\hline \multirow[t]{2}{*}{ People here tend to "live and let live" } & 2.57 & 3.08 & 3.27 \\
\hline & AVG $\quad 2.03$ & AVG $\quad 2.55$ & $\begin{array}{ll}\text { AVG } 3.41 \\
\end{array}$ \\
\hline
\end{tabular}

Table 4: Generational Perceptions Compared

Scale: $1=$ disagree completely to $5=$ agree completely

\section{Small Town}

\section{Baby Boomer Generation $(\mathbf{n}=\mathbf{2 5})$}

Hold traditional values (3.7)

Expected to conform here (3.4)

The heart of America (3.3)

Narrow minded (2.9)

Volunteer to help neighbors (2.2)

\section{Suburbia}

Baby Boomer Generation $(\mathbf{n}=\mathbf{2 5})$

Place to raise kids (4.1)

Soccer Moms (3.6)

Volunteer to help neighbors (3.7)

Heart of America (3.5)

Hold traditional values (3.4)

City

Baby Boomer Generation $(\mathbf{n}=\mathbf{2 5})$

Dangerous (3.4)

Free to discover myself (3.4)

Where the latest trends start (3.3)

Status is based on money (3.1)

People tend to "live and let live" (3.1)

\section{Millennial Generation $(\mathbf{n}=\mathbf{2 5})$}

Hold traditional values (4.2)

Volunteer to help neighbors (3.4)

The heart of America (3.4)

Expected to conform here (3.2)

Narrow minded (3.2)

Millennial Generation $(\mathbf{n}=\mathbf{2 5})$

Place to raise kids (4.1)

Soccer Moms (4.0)

Volunteer to help neighbors (4.0)

Hold traditional values (3.7)

Like the place I grew up (3.2)

Millennial Generation $(\mathbf{n}=\mathbf{2 5})$

Status is based on money (3.9)

Place to live before I settle down (3.8)

Dangerous (3.6)

Where the latest trends start (3.6)

Free to discover myself (3.5) 
Table 5 - Sources of Community Perceptions

Books Read
\begin{tabular}{|l|l|}
\hline Baby Boomer Generation (n=25) & Millennial Generation $(\mathbf{n = 2 5})$ \\
\hline Tom Sawyer (25) & To Kill a Mockingbird (20) \\
\hline To Kill a Mockingbird (24) & The Scarlet Letter $(18)$ \\
\hline The Scarlet Letter (24) & Tom Sawyer (13) \\
\hline Catcher in the Rye (21) & Sex in the City (10) \\
\hline Death of a Salesman (17) & Catcher in the Rye (9) \\
\hline Fahrenheit 451 (16) & Fahrenheit 451 (8) \\
\hline Sex in the City (12) & Death of a Salesman (6) \\
\hline
\end{tabular}

TV Shows Seen
\begin{tabular}{|l|l|}
\hline Baby Boomer Generation (n=25) & Millennial Generation $(\mathbf{n = 2 5})$ \\
\hline The Munsters (25) & The Brady Bunch $(22)$ \\
\hline Friends (24) & Friends (22) \\
\hline The Brady Bunch (24) & The Cosby Show (20) \\
\hline Leave It to Beaver (23) & Married with Children (18) \\
\hline Happy Days (23) & Good Times (17) \\
\hline Little House on the Prairie(22) & Little house on the Prairie (17) \\
\hline The Jeffersons (21) & Happy Days (15) \\
\hline The Partridge Family (21) & The Jeffersons $(15)$ \\
\hline Family Ties (21) & Beverly Hills $90210(13)$ \\
\hline Beverly Hills 90210 (19) & Leave it to Beaver (13) \\
\hline
\end{tabular}

\section{CONCLUSIONS, LIMITATIONS, AND RESEARCH IMPLICATIONS}

The qualitative analysis of the generational subsamples indicates support for the idea that the three community types are associated with consistent sets of images and attributes over time, supporting their character as naturally occurring brands. In the current survey participants characterize them similarly as the boomers did in the ethnography 25 years ago. In addition, today's millennials understand them the same way as both examples of the boomer generation do. This study supports the plausibility of the idea that each community type is a symbol and therefore a naturally occurring brand whose meaning is understood by a range of consumers.

In order to assert the validity of this new theoretical formulation of naturally occurring brands with confidence, two shortcomings need to be addressed. First, the data used for analysis is qualitative due to small sample sizes that obviate statistical analysis. Second, while this research investigates the possible consumerconstructed meanings of these brands of community, it does not directly measure whether the NOBs will affect where each person wants to live. Instead, the measures used to characterize each brand focus on the perceived nature and the quality of life of in each type of area.

\section{Theoretical and Practical Implications}

If the theoretical framework advanced in this paper withstands more rigorous scrutiny, the scholarly implications could be dramatic. First, the idea opens a whole new class of human symbols that may have been overlooked regarding their ability to influence consumer preferences. The presence of such a meta-level of symbol influence calls for research into a new dimension of meanings and signifiers that can affect our understandings about how humans congregate, interact, and interpret each other.

The study results could give rise to new questions and understandings regarding social structure, culture and processes in all the social science fields, especially in Anthropology, Sociology, Social Psychology and their applications to Marketing. The presence of an entire new layer of brands whose meaning arises from consumer experiences and perceptions rather than producer intentions also dramatically raises new questions for consumer researchers regarding marketplace brand competition. 
For practitioners, the most immediate impact of this new meta-level of symbols and meanings lies in determining how they influence actual human understanding, interpretation, choice and behavior. Marketers will need to redefine brand competitive sets. They will need to acknowledge the presence of alternative sources of perception and meaning form a context in which consumers evaluate commercially created and managed brands. Marketing communications and the research designed to measure their effectiveness would have to include a new dimension of diagnostic variables.

Real estate developers who create new communities will find the characterizations with each NOB useful in presenting their offerings. As a context for other types of products, services, and brands, the dramatization of naturally occurring community brand identities (positive and negative) are already affecting consumer responses, they are just not explicitly measured at the present time.

This research builds on and extends findings by previous scholars regarding brand symbolism and meaning, as well as the autonomy of consumers in contributing to both. It certainly would encourage commercial brand managers who market their offerings at the functional benefit level of imagery today to add the less tangible but no less influential symbolic aspects of meaning to their brand images.

\section{SUGGESTIONS FOR FUTURE RESEARCH}

This is an exploratory inquiry into the plausible validity of a new theoretical formulation. Before a more complete theory can be constructed, comprehensive research is needed to confirm or disconfirm hypotheses about the common meanings associated with each NOB. In addition, specific research is needed to measure how influential these NOBs are in helping consumers choose where to live.

In future studies a larger number of each generation should be surveyed so statistical tests can be performed concerning the direction and levels of agreement on how well each attribute cluster describes a specific brand of community. In addition, the differences in generational ratings should be submitted to statistical comparisons so it can be asserted with more confidence that the two generations share the same perceptions of each brand. If the theoretical conceptualization is sustained, theory can be expanded to consider what other meta-level symbols in our culture act as naturally occurring brands. Ultimately, the consistency of such patterns across cultures can also be examined. The sociological literature abounds in community ethnographies from other national regions that indicate the three types exist as actual community types in a variety of other national and ethnic cultures.

\section{ACKNOWLEDGEMENTS}

I thank the reviewers, and Dr. Ara Volkan, whose guidance as I make the transition from business executive to academic has been exemplary.

\section{AUTHOR INFORMATION}

Christine Wright-Isak earned her Ph.D. in Sociology from the University of Chicago going directly to industry where she became a branding specialist for clients such as GE, DuPont and Colgate-Palmolive. In 1999 she was awarded the Gold Ogilvy for best use of marketing research in the launch of a new product (Colgate Total in the U.S. market). In 2008 she helped Hanesbrands rebrand the Champion athletic-wear brand. She is currently an Assistant Professor of Marketing at the Lutgert College of Business at Florida Gulf Coast University. Her research interests include Brand Equity Management, New Product Branding and Military Branding. E-mail: cwright@fgcu.edu.

\section{REFERENCES}

1. $\quad$ Aaker, D. A. (1996). Building Strong Brands. New York: The Free Press.

2. Aaker, D. A., \& Biel, A. L. (1993). Brand Equity and Advertising. Hillsdale, NJ: Erlbaum \& Associates.

3. Anderson, E. (1978). A Place on the Corner. Chicago, IL, USA: University of Chicago Press. 
4. Belk, R., Sherry Jr. , J. F., \& Wallendorf, M. (1988). A Naturalistic Inquiry into Buyer and Seller Behavior at a Swap Meet. Journal of Consumer Research, 14, 449-470.

5. Boden, S., \& Williams, S. J. (2002). Consumption and Emotion: the Romantic Ethic Revisited. Sociology, 36 (2), 493-512.

6. Calkins, T. (2005). The Challenge of Branding. In A. M. Tybout, \& T. Calkins, Kellogg on Branding (pp. 1-8). Hoboken: John Wiley \& Sons.

7. Cohen, A. P. (1985). The Symbolic Construction of Community. New York: Methuen Incorporated.

8. Cova, B., \& Cova, V. (2001). Tribal Aspects of Postmodern Consumption Research: the Case of French Inline Roller Skates. Journal of Consumer Behavior , 1 (1), 67-76.

9. Crampton, S. M., \& Hodge, J. W. (2009). Generation Y: Uncharted Territory. Journal of Business and Economics Research, 7 (4), 1-6.

10. Duneir, M. (1989). Slim's Place, Race, Responsibility and Masculinity. Chicago, IL, USA: University of Chicago Press.

11. Fournier, S. (1998). Consumers and Their Brands: Developing Relationship Theory in Consumer Research. Journal of Consumer Behavior, 24, 342-373.

12. Gans, H. (1967). The Levittowners. New York: Vintage Books.

13. Hayden, D. (1976). Seven American Utopias, the architecture of Communitarian Socialism. Cambridge, MA, USA: MIT Press.

14. Holt, D. (2003). What Becomes an Icon Most. Harvard Business Review , 81 (3), 43-49.

15. Keller, K. L. (1998). Strategic Brand Management, Building, Measuring and Managing Brand Equity. Upper Saddle River: Prentice Hall.

16. Kornblum, W. (1974). Blue Collar Community. Chicago, IL, USA: University of Chicago Press.

17. Kotler, P., Haider, D. H., \& Rein, I. (1996). Marketing Places. New York: The Free Press.

18 Kotler, Philip and Armstrong, Gary. (2010). Principles of Marketing. Upper Saddle River: Prentice Hall.

19. McAlexander, J., Schouten, J. W., \& Koenig, H. F. (2002). Building Brand Community. Journal of Marketing , 66, 38-54.

20. Muniz, A. M., \& O'Guinn, T. C. (2001). Brand Community. Journal of Consumer Research , 27 (4), $412-$ 432.

21. Noble, S. M., Haytko, D. L., \& Phillips, J. (2009). What drives college-age Generation Y consumers? Journal of Business Research, 62, 617-628.

22. O'Guinn, T. C., \& Belk, R. (1989). Heaven on Earth: Consumption at Heritage Village, USA. Journal of Consumer Research, 16, 227-238.

23. Perin, C. (1977). Everything is in Place, Social Order and Land Use in America. Princeton: Princeton University Press.

24. Rust, R. T., Zeithaml, V. A., \& Lemon, K. N. (2004, September). Customer-Centered Brand Management. Harvard Business Review, 110-118.

25. Schouten, J. W., \& McAlexander, J. H. (2005). Subcultures of Conscription: An Ethnography of the New Bikers. Journal of Consumer Research, 22, 43-61.

26. Sherry Jr., J. F. (1990). A Sociocultural Analysis of a Midwestern American Flea Market. Journal of Consumer Research, 17, 13-30.

27. Sherry, J. F. (2005). Kellog on Branding. In A. Tybout, \& T. Calkins (Eds.). Hoboken, New Jersey, United States: John Wiley and Sons.

28. Suttles, G. D. (1968). The Social Order of Slum. Chicago: University of Chicago Press.

29. Thomson, M. D., MacInnis, D. J., \& Park, C. W. (2005). The Ties That Bind: Measuring the Strength of Consumers' Emotional Attachment to Brands. Journal of Consumer Psychology , 15 (1), 77-91.

30. Tybout, A., \& Sternthal, B. (2005). Brand Positioning. In A. Tybout, \& T. Calkins, Kellogg on Branding (pp. 11-26). Hoboken, NJ: John Wiley \& Sons.

31. Veloutsou, C. (2007). Identifying Dimensions of the Product-Brand and Consumer Relationship. Journal of Marketing Management, 23 (.5), 7-26.

32. Veloutsou, C., \& Moutinho, L. (2009). Brand Relationships through Brand Reputation and Brand Tribalism. Journal of Business Research, 62, 314-322.

33. Vidich, A., \& Bensman, J. (1968). Small Town in Mass Society. New York: Prentice Hall.

34. Wright-Isak, C. (1985). The Defended Community. Unpub. Doctoral Thesis . Chicago, IL: University of Chicago. 
35. Zablocki, B. (1981). Alienation and Charisma. New York: The Free Press.

36. Zablocki, B. (1979). The Joyful Community. Chicago: University of Chicago Press.

\section{NOTES}

